\title{
Chemical Composition and Antioxidant Properties of Oils from the Seeds of Five Apricot (Prunus armeniaca L.) Cultivars
}

\author{
Małgorzata Stryjecka ${ }^{1}$, Anna Kiełtyka-Dadasiewicz ${ }^{2 *}$, Monika Michalak ${ }^{3}$, \\ Leszek Rachoń ${ }^{2}$, and Aleksandra Głowacka ${ }^{2}$ \\ ${ }^{1}$ Institute of Agricultural Sciences, State School of Higher Education in Chełm, Pocztowa 54, 22-100 Chełm, POLAND \\ ${ }^{2}$ Department of Plant Production Technology and Commodity Science, University of Life Sciences in Lublin, Akademicka 15, 20-950 Lublin, \\ POLAND \\ ${ }^{3}$ Department of Dermatology and Cosmetology, Institute of Medical Sciences, Faculty of Medicine and Health Sciences, Jan Kochanowski \\ University in Kielce, IX Wieków Kielc 19, 25-317 Kielce, POLAND
}

\begin{abstract}
Oils from five cultivars of apricot (Prunus armeniaca L.) grown in Poland were analysed for characteristics of chemical and biological activity. The extracted oils had an average iodine value (g of I/100 $\mathrm{g}$ of oil) of 99.2; a refractive index of $\left(40^{\circ} \mathrm{C}\right) 1.4675$; a saponification value of $189 \mathrm{mg} \mathrm{of} \mathrm{KOH} / \mathrm{g}$ of oil; and $\mathbf{0 . 6 8 \%}$ unsaponifiable matter. As regards the oxidation state, the specific extinction values of the oils at 232 and $268 \mathrm{~nm}$ were 2.55 and 0.94 , respectively, while the peroxide value was $1.40 \mathrm{meq} \mathrm{O}_{2} / \mathrm{kg}$ and the panisidine value was $\mathbf{1 . 4 2}$. Oleic acid $(\mathbf{7 0 . 7 0} \%)$ was the predominant fatty acid found in the oils, followed by linoleic $(22.41 \%)$, palmitic $(3.14 \%)$, stearic $(1.4 \%)$, linolenic $(0.90 \%)$, and palmitoleic $(0.70 \%)$ acid. The content of $\alpha$-, $\gamma$-, and $\delta$ - tocopherols in the oils from the five apricot cultivars was 19.6-40.0, 315.4-502.3, and $28.3-58.5 \mathrm{mg} / \mathrm{kg}$, respectively. The antioxidant capacity of the apricot kernel oils, measured using the FRAP assay, ranged from 1.07 to $1.38 \mathrm{mM} \mathrm{Fe} e^{2+} / \mathrm{L}$, while total polyphenols and $\beta$-carotene content were 0.85-1.22 mM gallic acid/L and $42.3-66.8 \mu \mathrm{g} / \mathrm{g}$, respectively. The results indicate that among the cultivars tested, the 'Somo' cultivar grown in Poland provides the most oil, with the highest antioxidant activity. The results of our study demonstrate that apricot seeds are a potential source of oil that can have both dietary and cosmetic applications.
\end{abstract}

Key words: Prunus armeniaca, apricot oil, chemical characteristics, fatty acids, antioxidant properties

\section{Introduction}

Vegetable oils are an essential element of the diet contributing to preservation of health, but they also have a significant role in skin care. Among vegetable fats, an important group comprised fruit seed oils, which play an important role in health prophylaxis. Owing to their beneficial effects on the skin, they are used in cosmetology as well ${ }^{1}$. Alongside other oils in this group, apricot kernel oil is valuable and worthy of interest ${ }^{2}$.

Apricot(Prunus armeniaca L.), a plant of the family Rosaceae, well-known for its delicious fruit, is widely distributed in most countries of the world ${ }^{2-4}$. The fruit of the apricot is distinguished by high dietary value and is a valuable raw material for the processing industry. The kernel is a good source of protein, essential amino acids, carbohy- drates, and lipids in human nutrition ${ }^{5,6}$. The oil obtained from apricot seeds, which is pale yellow and tasteless, can be used in various edible, cosmetic, scent and industrial preparations $^{6-8)}$. Apricot kernel oil is a significant source of saturated and unsaturated fatty acids, including palmitic, stearic, myristic, oleic, palmitoleic, linoleic and linolenic $\operatorname{acid}^{6,7,9)}$. It also contains phytosterols (e.g. campesterol, stigmasterol, and sitosterol), polyphenols, carotenoids, $\alpha-$, $\gamma$ - and $\delta$-tocopherol, other vitamins (vitamin C, thiamin, riboflavin and niacin) and minerals ( $\mathrm{Na}, \mathrm{K}, \mathrm{Ca}, \mathrm{P}, \mathrm{Mg}, \mathrm{Zn}, \mathrm{Fe}$ and $\mathrm{Mn})^{3,4,6,7,10,11)}$. The apricot and the oil obtained from it have been used in folk medicine as a remedy for various diseases, including asthma, constipation, cough, vaginal infections, furuncle, acne vulgaris, dandruff or skin irrita$\operatorname{tion}^{11-13}$. Even today, apricot oil is used for its antibacteri-

\footnotetext{
*Correspondence to: Anna Kiełtyka-Dadasiewicz, Department of Plant Production Technology and Commodity Science, University of Life Sciences in Lublin, Akademicka 15, 20-950 Lublin, POLAND

E-mail: anna.kieltyka-dadasiewicz@up.lublin.pl

Accepted May 20, 2019 (received for review May 7, 2019)

Journal of Oleo Science ISSN 1345-8957 print / ISSN 1347-3352 online

http://www.jstage.jst.go.jp/browse/jos/ http://mc.manusriptcentral.com/jjocs
} 
al (Staphylococcus aureus and Escherichia coli), antifungal (Candida albicans, and Candida glabrata) and antioxidant activity ${ }^{11,14)}$. Applied externally, owing to components such as triglycerides, phospholipids, FFAs, phenolic compounds, and antioxidants, the oil protects the skin against the adverse effects of free radicals, exhibits anti-inflammatory activity, and also promotes skin barrier homeostasis and wound healing ${ }^{14,15)}$. It is well absorbed and does not leave an oily feel on the skin. It is used in many cosmetic products, such as moisturizing creams, face scrubs or lip balms ${ }^{16,17}$. It is also used as a hair, body, massage or baby oil, as well as a UV protection agent ${ }^{16,18)}$. Apart from the wide use of apricot kernel oil in the cosmetics and pharmaceutical industries (e.g. to relieve backache and joint aches), it can also be used for edible purposes, due to its considerable nutritive value $e^{9,16,19,20)}$.

The apricot is a temperate-zone fruit from Asia, with the largest plantations currently located in Turkey, Uzbekistan, Italy, Algieria and $\operatorname{Iran}^{21)}$. New varieties of this species, adapted to growth in a slightly cooler climate, are continually emerging. Apricots have been grown for fruit on plantations in Poland for over a decade (1335 tonnes in 2017, which ranks 50th in the world $)^{21,22)}$. There is no processing plant in Poland that acquires oil from apricot seeds, and there is no information in the literature on the yield and quality of apricot kernel oil of Polish origin ${ }^{23)}$. Therefore, the aim of our work is to analyse the yield, chemical characteristics and antioxidant properties of oils obtained from the seeds of five apricot cultivars grown in Poland.

\section{Experimental}

\subsection{Plant material}

The material for the research consisted of the seeds of five cultivars of apricot (Prunus armeniaca L.): 'Early Orange', 'Goldrich Sungiant', 'Harcot', 'Hargrand' and 'Somo' . Apricot fruit was harvested in August 2016 from 4-year-old trees grown in an organic orchard in south-eastern Poland, near Chełm ( $\left.51^{\circ} 7^{\prime} 56^{\prime \prime} \mathrm{N}, 23^{\circ} 28^{\prime} \quad 40^{\prime \prime} \mathrm{E}\right)$. Immediately after harvesting, the seeds were hand-separated from the fruit, washed with tap water and dried at $40^{\circ} \mathrm{C}$ in a drying oven (Memmert GmbH \& Co. KG (Germany) for 24 h.

\subsection{Extraction of seed oil}

After removal of the seed coating, seed kernel samples (50 g of each cultivar) were crushed in a commercial blender (MICROTRON ${ }^{\circledR}$ MB 550, Germany). The crushed material, packed in a paper thimble, was placed in a Soxhlet extractor connected to a condenser and a $500 \mathrm{~mL}$ round-bottom flask. The extraction was performed with n-hexane $(250 \mathrm{~mL})$ in a water bath for $10 \mathrm{~h}$. Then the solvent was removed under reduced pressure using a rotary evaporator (Rotavapor ${ }^{\circledR}$ R-100, Buchi Labortechnik AG, Switzerland).

\subsection{Analysis of the main components of the defatted seeds}

The oil seed residues remaining after oil extraction were analysed for protein, ash, fibre and moisture content. Protein content was determined by the Kjeldahl method according to the International Organization for Standardization (ISO $)^{24)}$. For determination of crude ash residue content, samples were incinerated at $550^{\circ} \mathrm{C}$ to a constant weight in a muffle furnace (L 9/11/SKM, Nabertherm, Germany), cooled in a desiccator, and weighed to the nearest $0.001 \mathrm{~g}$, according to ISO 5984:2002 ${ }^{25}$. Crude fibre content was determined manually according to II ${ }^{26)}$. Moisture content was determined by the oven-drying method at $105^{\circ} \mathrm{C}$ in a Memmert GmbH \& Co. KG drying oven (Germany) according to ISO 6496:1999 ${ }^{27)}$.

\subsection{Analysis of the chemical properties of apricot seed oils}

Selected chemical properties were determined in the oils: saponification value, unsaponifiable matter, refractive index, and iodine value. The saponification value was determined by potentiometric titration according to ISO 3657:2013 ${ }^{28}$. The measurements were made with an AT 1000 automatic titrator. Unsaponifiable matter was determined by titration using $0.02 \mathrm{~N} \mathrm{NaOH}$, according to the guidelines of AOAC International ${ }^{29)}$.

The refractive index was measured using an Abbe refractometer(NAR-2T, Atago, Japan) at $40^{\circ} \mathrm{C}$, according to ISO $6320: 2000^{30)}$. The iodine value was determined according to $\mathrm{AOAC}^{31)}$ by titration with $0.1 \mathrm{~N}$ sodium thiosulphate solution.

\subsection{Fatty acid composition analysis}

Fatty acid profiles were measured by gas chromatography according to ISO standards ${ }^{32,33}$. The oil samples (100 $\mathrm{mL}$ each)were converted to their fatty acid methyl esters (FAME). The methyl ester fatty acid samples were analysed in a gas chromatograph (Shimadzu GC-2010 PLUS) equipped with a flame ionisation detector.

A highly polar BPX 70 capillary column $(60 \mathrm{~m} \times 0.25 \mathrm{~mm}$, $25 \mu \mathrm{m}$ ) was used for the separation. The column was programmed in a temperature range from 140 to $210^{\circ} \mathrm{C}$, the dosing temperature was $210^{\circ} \mathrm{C}$, and the detector temperature was set to $250^{\circ} \mathrm{C}$. The carrier gas was 6.0 helium, with a constant flow rate of $2 \mathrm{~mL} / \mathrm{min}$.

\subsection{Content of total polyphenols, $\beta$-carotene and tocoph- erols}

Tocopherol content was determined by HPLC (HP 1100 with a UV detector) according to PN-EN 12822:2014-08 ${ }^{34)}$. The analysis was carried out in the reversed phase mode. 
The oil sample was dissolved in methanol and then applied to the top of a Supelcosil LC-18 column $(25 \mathrm{~cm} \times 4.6 \mathrm{~mm}, 5$ $\mu \mathrm{m})$. The separation was carried out at $30^{\circ} \mathrm{C}$. The mobile phase was methanol/water $(97: 3, \mathrm{v} / \mathrm{v})$ and the flow time was $1 \mathrm{~mL} / \mathrm{min}$. Individual $\alpha, \gamma$ and $\delta$ isomers were determined at $292 \mathrm{~nm}$.

The content of carotenoids in the oils was determined by spectrophotometry ${ }^{35)}$ and expressed as $\beta$-carotene. The measurements were performed with a colorimeter(Tintometer Ltd Lovibond PFX 990, England), and the absorbance was measured at $445 \mathrm{~nm}$.

Determination of the total polyphenol content (TPC) was based on the Folin-Ciocalteu total phenolic assay ${ }^{36)}$, using gallic acid as reference standard. Absorbance of the samples was measured with a UV-Vis spectrophotometer (UV-2600, Shimadzu, Japan) at $725 \mathrm{~nm}$. The results were expressed as gallic acid equivalent(mg GAE per L of oil).

\subsection{Total antioxidant capacity}

Extracts containing the polar fraction of the oils were prepared according to Szydłowska-Czerniak et al. ${ }^{37)} \mathrm{A} 10$ $\mathrm{mL}$ volume of methanol and water $(70: 30 \mathrm{v} / \mathrm{v})$ was added to $2 \mathrm{~g}$ of oil and extraction was carried out for $1 \mathrm{~h}$ without access to light. The samples were then frozen at $-20^{\circ} \mathrm{C}$ for another hour until the layers were separated. The extract was separated from the oil by quantitative transfer to glass flasks and stored in a freezer $\left(-20^{\circ} \mathrm{C}\right)$ until analysis.

The reducing properties of the extracts were evaluated using a the FRAP assay (ferric reducing antioxidant power) ${ }^{38}$ ), which is based on estimation of the capacity of the test substance to reduce the TPTZ-Fe ${ }^{3+}$ iron complex (2,4,6-tripyridyl-s-triazine iron complex) to TPTZ-Fe ${ }^{2+}$. This reduction is accompanied by a decrease in the absorbance of the reaction system, which was measured by spectrophotometry(UV-2600, Shimadzu, Japan) at $593 \mathrm{~nm}$. The FRAP of the oil extracts was determined according to Benzie and Strain $^{38)}$ with modifications proposed by Szydłowska-Czerniak et $a l .{ }^{37)}$. For this purpose a reaction mixture was prepared containing $10 \mathrm{mM} / \mathrm{L}$ TPTZ solution in $40 \mathrm{mM} / \mathrm{L} \mathrm{HCl}, 20 \mathrm{mM} / \mathrm{L} \mathrm{FeCl}_{3}$, and $0.1 \mathrm{mM} / \mathrm{L}$ acetate buffer $(\mathrm{pH}=3.6)$ in a $1: 1: 10$ ratio. A $0.3 \mathrm{~mL}$ volume of extract from the oil samples and $2 \mathrm{~mL}$ of reaction mixture were combined and made up to $10 \mathrm{~mL}$ with distilled water. The samples were mixed and left for $10 \mathrm{~min}$ at room temperature. The samples were then centrifuged for $10 \mathrm{~min}$ and the absorbance was measured against the control sample $(2 \mathrm{~mL}$ of the reaction mixture was placed in a 10 $\mathrm{mL}$ volumetric flask and made up to volume with distilled water). The FRAP value (mM Trolox/L of oil) of individual samples was determined on the basis of a standard curve prepared using Trolox solution in a concentration range of $0-0.02 \mu \mathrm{M} / \mathrm{mL}$ of the reaction mixture.

\subsection{Analysis of the oxidative stability of the oils}

The oxidative stability of the oils was determined based on the peroxide value (PV), $\mathrm{p}$-anisidine value ( $\mathrm{p}-\mathrm{AV})$, and conjugated dienes $(\mathrm{CD})$ and trienes $(\mathrm{CT})$. PV was determined by titration of the sample with $0.01 \mathrm{~N} \mathrm{Na}_{2} \mathrm{~S}_{2} \mathrm{O}_{3}$. The analysis was carried out according to ISO 3960:2007 ${ }^{39)}$ by iodometric (visual) endpoint determination. The p-AV was determined according to the AOCS Official Method ${ }^{40)}$, which involves spectrophotometric (UV-2600 Shimadzu, Japan) determination of the absorbance of the sample at $350 \mathrm{~nm}$ using $0.25 \% \mathrm{p}$-anisidine in glacial acetic acid.

Conjugated dienes (CD) and conjugated trienes (CT) were determined according to methods recommended by IUPAC $^{41)}$. Apricot oil samples were diluted with isooctane to bring the absorbance to within limits. The absorbance was measured at $232 \mathrm{~nm}$ and $268 \mathrm{~nm}$ for conjugated dienes and trienes, respectively (UV 2600 Shimadzu, Japan).

\subsection{Statistical analysis}

Analysis of all parameters in the apricot oil samples was performed in triplicate. Statistica 9.0 StatSoft was used to analyse the data. One-way ANOVA with the Tukey test was used to evaluate the significant differences between means at $p<0.05$. A dendrogram was obtained by hierarchical cluster analysis, taking into account the numerical data for all parameters tested in the seeds and oils, using Euclidean distances between individual data points.

\section{Results and Discussion}

\subsection{Seed properties}

The oil content in the seeds of five apricot cultivars was analysed, as well as the content of proteins, ash, fibre and moisture in the pomace after oil extraction. For each of these traits, significant variation was noted between cultivars (Table 1). The seeds of apricots grown in Poland proved to be rich in oil (37\% on average), but the differences for individual cultivars were substantial. The most oil $(44.2 \%)$ was found in the seeds of the 'Somo' cultivar, which corresponded to the lowest moisture content of defatted seeds. The least oil was found for the 'Harcot' cultivar, but the pomace of this cultivar had the highest moisture content. Analogous relationships for these cultivars were observed for protein content. The protein content in the pomace following oil extraction was high, and ranged from $14.9 \%$ for the 'Goldrich Sungiant' cultivar to $19.2 \%$ for 'Somo'. The highest content of ash and fibre was found in the defatted seeds of the 'Hargrand' cultivar, with $4.82 \%$ and $9.17 \%$, respectively.

High oil content in apricot seeds (mean $=37 \%$ ) indicates that they are suitable for industrial production of vegetable oil. The protein concentration of the seeds of apricots from Poland was found to be lower than that of Prunus arme- 
M. Stryjecka, A. K.-Dadasiewicz, M. Michalak et al.

Table 1 Percentage content of the most important seed components.

\begin{tabular}{cccccc}
\hline Apricot cultivars & Oil & Moisture & Protein & Ash & Fibre \\
\hline 'Early Orange' & $35.4^{\mathrm{b}}$ & $5.17^{\mathrm{c}}$ & $16.2^{\mathrm{c}}$ & $3.07^{\mathrm{a}}$ & $5.17^{\mathrm{a}}$ \\
'Goldrich Sungiant' & $34.2^{\mathrm{b}}$ & $5.29^{\mathrm{cd}}$ & $14.9^{\mathrm{a}}$ & $3.27^{\mathrm{b}}$ & $6.54^{\mathrm{b}}$ \\
'Harcot' & $32.2^{\mathrm{a}}$ & $5.43^{\mathrm{d}}$ & $15.6^{\mathrm{b}}$ & $3.24^{\mathrm{b}}$ & $8.23^{\mathrm{d}}$ \\
'Hargrand' & $39.2^{\mathrm{c}}$ & $4.91^{\mathrm{b}}$ & $18.2^{\mathrm{d}}$ & $4.82^{\mathrm{d}}$ & $9.17^{\mathrm{e}}$ \\
'Somo' & $44.2^{\mathrm{d}}$ & $4.30^{\mathrm{a}}$ & $19.2^{\mathrm{e}}$ & $4.16^{\mathrm{c}}$ & $7.31^{\mathrm{c}}$ \\
\hline Mean & 37.0 & 5.02 & 16.9 & 3.71 & 7.28 \\
\hline
\end{tabular}

Values marked with the same superscript letter do not differ significantly.

Table 2 Physicochemical characteristic of oils from the seeds of five apricot cultivars.

\begin{tabular}{ccccc}
\hline Apricot cultivars & $\begin{array}{c}\text { Saponification } \\
\text { value (mg of } \\
\text { KOH/g of oil) }\end{array}$ & $\begin{array}{c}\text { Unsaponifiable } \\
\text { matter (\%) }\end{array}$ & $\begin{array}{c}\text { Refractive index } \\
\left.\text { (at 40 } 40^{\circ}\right)\end{array}$ & $\begin{array}{c}\text { Iodine value } \\
\text { (g of I/100 g } \\
\text { of oil) }\end{array}$ \\
\hline 'Early Orange' & $185^{\mathrm{a}}$ & $0.65^{\mathrm{b}}$ & $1.4449^{\mathrm{a}}$ & $95.7^{\mathrm{a}}$ \\
'Goldrich Sungiant' & $186^{\mathrm{a}}$ & $0.58^{\mathrm{a}}$ & $1.4666^{\mathrm{b}}$ & $98.5^{\mathrm{b}}$ \\
'Harcot' & $188^{\mathrm{a}}$ & $0.75^{\mathrm{c}}$ & $1.4721^{\mathrm{c}}$ & $101.8^{\mathrm{e}}$ \\
'Hargrand' & $195^{\mathrm{b}}$ & $0.81^{\mathrm{d}}$ & $1.4785^{\mathrm{e}}$ & $100.5^{\mathrm{d}}$ \\
'Somo' & $194^{\mathrm{b}}$ & $0.62^{\mathrm{b}}$ & $1.4755^{\mathrm{d}}$ & $99.7^{\mathrm{c}}$ \\
\hline Mean & 189 & 0.68 & 1.4675 & 99.2 \\
\hline
\end{tabular}

Values marked with the same superscript letter do not differ significantly.

niaca L. grown in India $(31.18 \%)^{7)}$ or New Zealand $(20.6 \%)^{42}$, but comparable to cultivars found in Turkey $(15.7-17.1 \%)^{5}$. The results obtained for content of moisture (mean 5.02\%), ash (mean 3.71\%) and fibre(mean $7.28 \%$ ) were in general agreement with those reported in the literature: $4.91-5.12 \%{ }^{43)}, 2.91-3.83 \%{ }^{5)}$ and $5.13-9.81 \%{ }^{10)}$, respectively.

\subsection{Physicochemical characteristics of oils}

The values for saponification, iodine value, unsaponifiable matter and refractive index for the apricot seed oils are presented in Table 2. The saponification value is used to check for adulteration and indicates the suitability of an oil in industry ${ }^{944)}$. The extracted oils had an average saponification value of $189 \mathrm{mg}$ of $\mathrm{KOH} / \mathrm{g}$ of oil; $0.68 \%$ unsaponifiable matter; and an iodine value ( $\mathrm{g}$ of $\mathrm{I} / \mathrm{100} \mathrm{g}$ of oil) of 99.2. These findings are in general agreement with results obtained by Manzoor et al. ${ }^{10}$ : $189.1-199.4 \mathrm{mg}$ of $\mathrm{KOH} / \mathrm{g}$ oil; $0.59-0.88 \%$ unsaponifiable matter; and $96.4-106.3 \mathrm{~g}$ of $\mathrm{I} / 100 \mathrm{~g}$ of oil. The refractive index, which ranged from 1.4449 for the 'Early Orange' cultivar to 1.4785 for 'Hargrand', was within the range for many edible oils ${ }^{44}$.

The physicochemical properties of oil depend on two groups of fatty acids - saturated and unsaturated ${ }^{7)}$. The oils from all apricot cultivars tested had a high content of unsaturated fatty acids (93.5-95.6\%), of which monounsaturated acids (MUFA) were dominant, with over $70 \%$, while polyunsaturated fatty acids (PUFA) accounted for about $23 \%$. Saturated fatty acids (SFA) represented from $4 \%$ to $5.1 \%$. Comparison of some conventional oils (Fig. 1) indicates that total saturated and total unsaturated fatty acids are highly comparable in almond seed oil, avocado oil and apricot seed oil. This similarity is a further indication of the high value of apricot seed oil. Hence apricot seed oil may be suggested as a good alternative to avocado and almond seed oil for cosmetic and food purposes.

\subsection{Fatty acid composition}

Our study showed that oils obtained from five cultivars of apricot (Prunus armeniaca L.) cultivated in Poland contained palmitic, stearic, oleic, palmitoleic, linoleic and linolenic acids (Table 3 ). In general, the variation in the fatty acid profile for the cultivars was insignificant, but the differences were statistically significant in the case of stearic, linolenic and oleic acid. The most linolenic acid was noted in 'Early Orange' and 'Goldrich Sungiant', and the least in 'Somo' and 'Hargrand', which contained the most oleic acid $(71.3 \%$ and $71.4 \%$, respectively). The oils varied in stearic acid content, which was highest in the oil from the 'Goldrich Sungiant' cultivar, followed by 'Early Orange', 'Harcot', 'Hargrand', and finally 'Somo'.

The study showed that oleic and linoleic acids were present in significant amounts. These results are supported by Gupta et $a l .{ }^{17)}$, who reported oleic acid content in kernel oils varying between $62.07 \%$ and $70.06 \%$, while linoleic acid content ranged between $20.5 \%$ and $27.76 \%$. Similar 


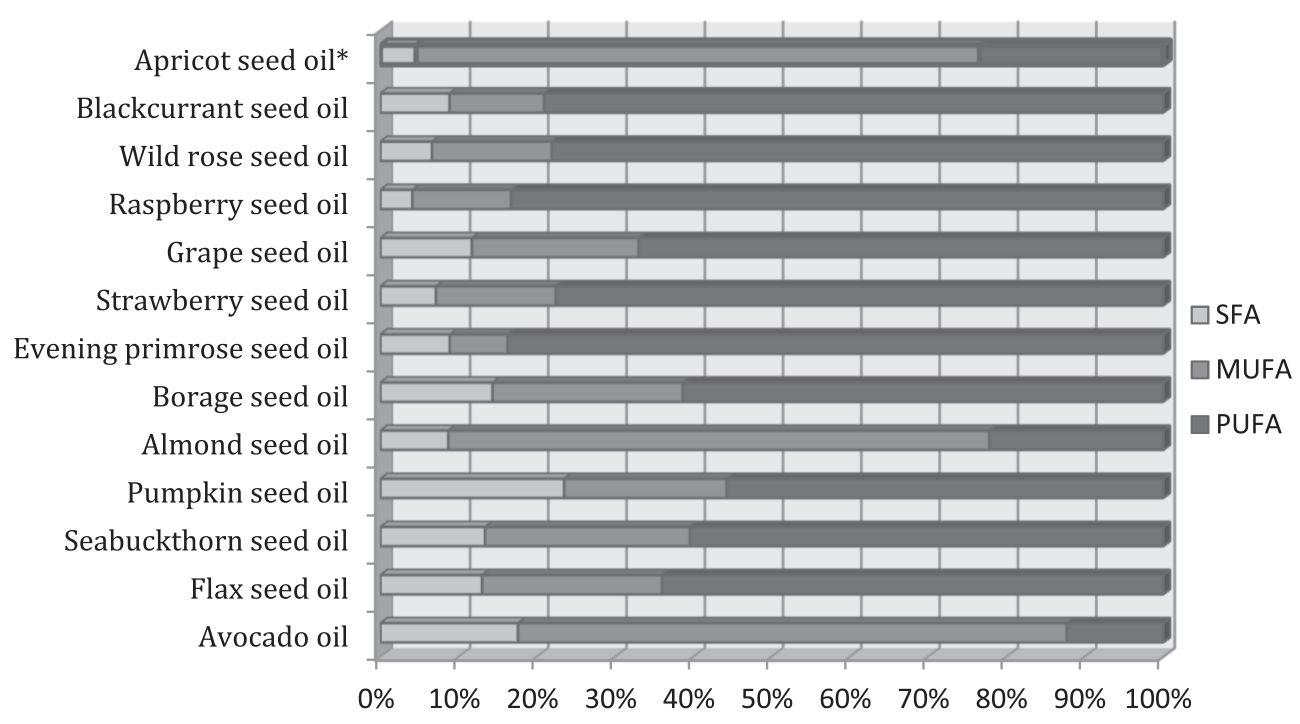

Fig. 1 Average fatty acid composition in apricot seed oils (mean for five cultivars) in comparison with selected conventional plant oils. (Source: own elaboration *data obtained from our own research; all other data from literature ${ }^{45-51)}$ ).

Table 3 Fatty acid composition in oils from the seeds of five apricot cultivars.

\begin{tabular}{ccccccc}
\hline \multirow{2}{*}{ Apricot cultivars } & \multicolumn{5}{c}{ Fatty acid content (\%) } \\
\cline { 2 - 7 } & $\begin{array}{c}\text { C 16:0 } \\
\text { Palmitic }\end{array}$ & $\begin{array}{c}\text { C 16:1 } \\
\text { Palmitoleic }\end{array}$ & $\begin{array}{c}\text { C 18:0 } \\
\text { Stearic }\end{array}$ & $\begin{array}{c}\text { C 18:1 } \\
\text { Oleic }\end{array}$ & $\begin{array}{c}\text { C18:2 } \\
\text { Linoleic }\end{array}$ & $\begin{array}{c}\text { C18:3 } \\
\text { Linolenic }\end{array}$ \\
\hline 'Early Orange' & $3.23^{\mathrm{a}}$ & $0.66^{\mathrm{a}}$ & $1.58^{\mathrm{d}}$ & $70.25^{\mathrm{ab}}$ & $22.10^{\mathrm{a}}$ & $1.02^{\mathrm{b}}$ \\
'Goldrich Sungiant' & $3.42^{\mathrm{a}}$ & $0.71^{\mathrm{a}}$ & $1.69^{\mathrm{e}}$ & $69.79^{\mathrm{a}}$ & $22.17^{\mathrm{a}}$ & $1.08^{\mathrm{b}}$ \\
'Harcot' & $3.19^{\mathrm{a}}$ & $0.75^{\mathrm{a}}$ & $1.51^{\mathrm{c}}$ & $70.74^{\mathrm{bc}}$ & $22.39^{\mathrm{a}}$ & $0.86^{\mathrm{ab}}$ \\
'Hargrand' & $3.09^{\mathrm{a}}$ & $0.65^{\mathrm{a}}$ & $1.13^{\mathrm{b}}$ & $71.43^{\mathrm{c}}$ & $22.69^{\mathrm{a}}$ & $0.74^{\mathrm{a}}$ \\
'Somo' & $2.93^{\mathrm{a}}$ & $0.71^{\mathrm{a}}$ & $1.06^{\mathrm{a}}$ & $71.30^{\mathrm{c}}$ & $22.71^{\mathrm{a}}$ & $0.78^{\mathrm{a}}$ \\
\hline Mean & 3.17 & 0.70 & 1.40 & 70.70 & 22.41 & 0.90 \\
\hline
\end{tabular}

Values marked with the same superscript letter do not differ significantly.

oil composition has been found in research by Beyer et $a l^{42)}$, in which the content of the dominant fatty acids was $69.0 \%$ and $26.0 \%$, respectively. Sharlatifar et $\left.a l .{ }^{9}\right)$ have shown that apricot kernel oil contains $60.01-70.56 \%$ oleic acid, 19.74-23.52\% linoleic acid, 2.35-5.97\% palmitic acid, $0.8-1.5 \%$ stearic acid, and $0.2-0.9 \%$ palmitoleic acid. Results of research by Turan et $a l .^{20}$ on the content of oleic (70.83\%), linoleic $(21.96 \%)$, palmitic $(4.92 \%)$ and stearic (1.21\%) acid were similar to our findings. The fatty acid composition of oil from apricot seeds (high content of monounsaturated oleic acid and low content of saturated fatty acids) is highly favourable in human nutrition. Oils high in oleic and linoleic acids play an important role in the human diet due to their superior stability and nutritional importance. Linoleic acid is recognized as one of the most important polyunsaturated fatty acids due to its healthpromoting properties in the case of various diseases, especially allergic, inflammatory and cardiovascular diseases ${ }^{10,52}$. Vegetable oils rich in unsaturated fatty acids also have a significant beneficial effect on the appearance and function of the skin ${ }^{1,53,54)}$. Vegetable fats strengthen the skin protection barrier, promote restoration of the stratum corneum lipid layer, prevent transepidermal water loss (TEWL), normalize sebaceous glands, reduce the negative effects of UV radiation on the skin, and prevent photoaging of the skin. Symptoms of fatty acid deficiency include epidermal dryness, peeling, skin flaccidity, inflammation, dermatosis, increased susceptibility to irritation, and a slowed healing process $^{53-56)}$. The data on the fatty acid composition of apricot seed oils provides useful information regarding their potential applications.

\subsection{Antioxidant properties}

Table 4 presents the content of some bioactive compounds, such as total phenols, $\beta$-carotene, and tocopherols, in oil obtained from the seeds of five apricot cultivars, as well as its antioxidant properties. The results of the tests of antioxidant properties, expressed as the ability to 
M. Stryjecka, A. K.-Dadasiewicz, M. Michalak et al.

Table 4 Phytochemical compounds with antioxidant effects in oils from five apricot cultivars.

\begin{tabular}{|c|c|c|c|c|c|c|}
\hline \multirow{2}{*}{$\begin{array}{l}\text { Apricot } \\
\text { cultivars }\end{array}$} & \multirow{2}{*}{$\begin{array}{c}\text { TPC } \\
(\mathrm{mMGAE} / \mathrm{L})\end{array}$} & \multirow{2}{*}{$\begin{array}{c}\beta \text {-carotene } \\
(\mu \mathrm{g} / \mathrm{g} \text { oil })\end{array}$} & \multicolumn{3}{|c|}{ Tocopherol content $(\mathrm{mg} / \mathrm{kg})$} & \multirow{2}{*}{$\begin{array}{c}\text { FRAP } \\
\left(\mathrm{mM} \mathrm{Fe}^{2+} / \mathrm{L}\right)\end{array}$} \\
\hline & & & $\alpha-T$ & $\gamma-\mathrm{T}$ & $\delta-\mathrm{T}$ & \\
\hline 'Early Orange' & $0.87^{\mathrm{a}}$ & $55.5^{\mathrm{b}}$ & $25.4^{\mathrm{b}}$ & $447.1^{\mathrm{d}}$ & $52.6^{\mathrm{d}}$ & $1.07^{\mathrm{a}}$ \\
\hline 'Goldrich Sungiant' & $0.85^{\mathrm{a}}$ & $42.3^{\mathrm{a}}$ & $19.6^{\mathrm{a}}$ & $330.4^{\mathrm{b}}$ & $38.4^{\mathrm{b}}$ & $1.16^{\mathrm{a}}$ \\
\hline 'Harcot' & $0.99^{\mathrm{b}}$ & $58.8^{\mathrm{c}}$ & $34.5^{\mathrm{c}}$ & $315.4^{\mathrm{a}}$ & $28.3^{\mathrm{a}}$ & $1.28^{\mathrm{b}}$ \\
\hline 'Hargrand' & $1.10^{\mathrm{c}}$ & $62.9^{\mathrm{d}}$ & $38.2^{\mathrm{d}}$ & $358.0^{\mathrm{c}}$ & $42.7^{\mathrm{c}}$ & $1.32^{\mathrm{b}}$ \\
\hline 'Somo' & $1.22^{\mathrm{d}}$ & $66.8^{\mathrm{e}}$ & $40.0^{\mathrm{e}}$ & $502.3^{\mathrm{e}}$ & $58.5^{\mathrm{e}}$ & $1.38^{\mathrm{b}}$ \\
\hline Mean & 1.01 & 57.2 & 31.5 & 390.6 & 44.1 & 1.24 \\
\hline
\end{tabular}

Abbreviations: TPC - total phenolic content, GAE - gallic acid, $\alpha$-T $-\alpha$-tocopherol, $\gamma$-T $-\gamma$-tocopherol, $\delta$-T $\delta$-tocopherol, FRAP - ferric ion reducing antioxidant power. Values marked with the same superscript letter do not differ significantly.

reduce iron(III)ions, showed that the oils from the five cultivars can be divided into two groups according to reduction potential. The oils of 'Early Orange' and 'Goldrich Sungiant' had lower reducing power than the others. The antioxidant activity of the oils originating in Poland, determined by the FRAP method, ranged from 1.07 to $1.38 \mathrm{mM}$ $\mathrm{Fe}^{2+} / \mathrm{L}$ and was comparable to that of oil harvested in western Romania $\left(0.86-1.33 \mathrm{mM} \mathrm{Fe} \mathrm{Fe}^{2+} / \mathrm{L}\right)$, as reported by Popa et al. ${ }^{57)}$.

Apricot seed oil contains many different bioactive compounds, including polyphenols, $\beta$-carotene and tocopher$\mathrm{ols}^{11)}$. They act as antioxidants that protect cells, tissues and the human body against the destructive effects of free radicals $^{58-60)}$. Polyphenols are a very large and important group of natural compounds with multidirectional biological activity ${ }^{61,62}$. These compounds, included among potent exogenous antioxidants, have anti-inflammatory, antibacterial, antifungal, antiviral, anti-allergic, anti-cancer, photoprotective, vasoprotective and antioxidant effects ${ }^{61,63-65)}$. Polyphenols, like $\beta$-carotene, which determines epithelial growth, plays an important role in the wound healing process, protects against the harmful effects of UV, and fights cancer, also play an important role in skin care ${ }^{57,65,66)}$. Tocopherols, compounds which act as a source of natural antioxidants to prevent oxidative deterioration of the oil, are also important in human nutrition, playing an essential role in maintaining the stability and integrity of the cell membrane ${ }^{17,18)}$. While numerous studies have dealt with polyphenols, tocopherols and $\beta$-carotene in plant oils obtained from other seeds (e.g. sea buckthorn, cranberry, wild rose, grape, and raspberry seeds ${ }^{45,67-71)}$, few studies have been conducted on these compounds in oil obtained from apricot seeds.

In the present study, the 'Somo' cultivar had the highest content of polyphenols (1.22 mM GAE/L), while 'Goldrich Sungiant' and 'Early Orange' had the least $(0.85$ and 0.87 mM GAE/L, respectively). The polyphenol content values reported in this paper are in close agreement with results
(0.88-1.30 mM gallic acid/L) obtained by Popa et $a l^{57)}$.

The experimental data show that $\beta$-carotene content depends on the cultivar (Table 4). The highest content of $\beta$-carotene was observed in the 'Somo' cultivar $(66.8 \mu \mathrm{g} / \mathrm{g}$ oil), and the lowest in 'Goldrich Sungiant' ( $42.3 \mu \mathrm{g} / \mathrm{g}$ oil). The analysis revealed that the level of $\beta$-carotene (on average $57.2 \mu \mathrm{g} / \mathrm{g}$ oil) was in close agreement with values $\left(\right.$ mean $=61.05 \mu \mathrm{g} / \mathrm{g}$ oil) reported in similar studies ${ }^{57}$.

The results of the research presented in this paper indicate that the apricot cultivar significantly influenced the content of tocopherols, among which $\gamma$-tocopherol was dominant (Table 4). The tocopherol concentrations reported here are in close agreement with those reported by Manzoor et al. ${ }^{10)}$ for $\alpha$-tocopherol (14.8-40.4 mg/kg), $\gamma$-tocopherol (330.8-520.8 mg/kg) and $\delta$-tocopherol (28.5$60.2 \mathrm{mg} / \mathrm{kg}$ ) in various cultivars of apricot kernel oils. Our results regarding the content of tocopherols are also supported by Turan $e t a l^{20)}$, who found $\alpha$-, $\gamma$ - and $\delta$-tocopherol levels of $14.89-26.87 \mathrm{mg} / \mathrm{kg}, 346.53-563.40 \mathrm{mg} / \mathrm{kg}$, and $8.56-18.94 \mathrm{mg} / \mathrm{kg}$, respectively ${ }^{20)}$. Among the five tested apricot cultivars, the most valuable oil in terms of content of polyphenols, $\beta$-carotene and tocopherols was the oil obtained from the seeds of the 'Somo' cultivar. In consequence, this oil also had the highest ferric ion reducing antioxidant power (FRAP).

\subsection{Oxidative stability of apricot seed oils}

Analytical methods such as determination of peroxide value $(\mathrm{PV})$, $\mathrm{p}$-anisidine value $(\mathrm{p}-\mathrm{AV})$ and content of conjugated dienes $(\mathrm{CD})$ and trienes $(\mathrm{CT})$ are used to measure primary or secondary products of accelerated oil oxidation induced by exogenous oxidation promoters and/or elevated temperature ${ }^{45}$. The quality of the oils from the five apricot cultivars was evaluated in terms of characteristics that could affect their oxidative stability (Table 5). In all oils the peroxide value (average $1.40 \mathrm{meq} \mathrm{O}_{2} / \mathrm{kg}$ ) was within the normal range, which should not exceed 10 milliequivalents of active oxygen $/ \mathrm{kg}$ oil for refined oils, or 15 milliequiva- 
Table 5 Oxidative stability of oils from the seeds of five apricot cultivars.

\begin{tabular}{ccccc}
\hline Apricot cultivars & p-anisidine value & $\begin{array}{c}\text { Peroxide value } \\
\left(\mathrm{meq} \mathrm{O}_{2} / \mathrm{kg}\right)\end{array}$ & $\begin{array}{c}\text { Conjugated dienes } \\
\mathcal{E}^{1 \%}{ }_{1 \mathrm{~cm}} \lambda_{232}\end{array}$ & $\begin{array}{c}\text { Conjugated trienes } \\
\mathcal{E}^{1 \%}{ }_{1 \mathrm{~cm}} \lambda_{268}\end{array}$ \\
\hline 'Early Orange' & $1.65^{\mathrm{c}}$ & $1.60^{\mathrm{c}}$ & $2.55^{\mathrm{b}}$ & $0.91^{\mathrm{ab}}$ \\
'Goldrich Sungiant' & $1.20^{\mathrm{ab}}$ & $1.07^{\mathrm{a}}$ & $2.10^{\mathrm{a}}$ & $1.07^{\mathrm{c}}$ \\
'Harcot' & $1.24^{\mathrm{b}}$ & $1.14^{\mathrm{b}}$ & $2.17^{\mathrm{a}}$ & $0.95^{\mathrm{b}}$ \\
'Hargrand' & $1.18^{\mathrm{a}}$ & $1.02^{\mathrm{a}}$ & $3.03^{\mathrm{d}}$ & $0.87^{\mathrm{a}}$ \\
'Somo' & $1.85^{\mathrm{d}}$ & $2.17^{\mathrm{d}}$ & $2.88^{\mathrm{c}}$ & $0.92^{\mathrm{ab}}$ \\
\hline Mean & 1.42 & 1.40 & 2.55 & 0.94 \\
\hline
\end{tabular}

Values marked with the same superscript letter do not differ significantly.

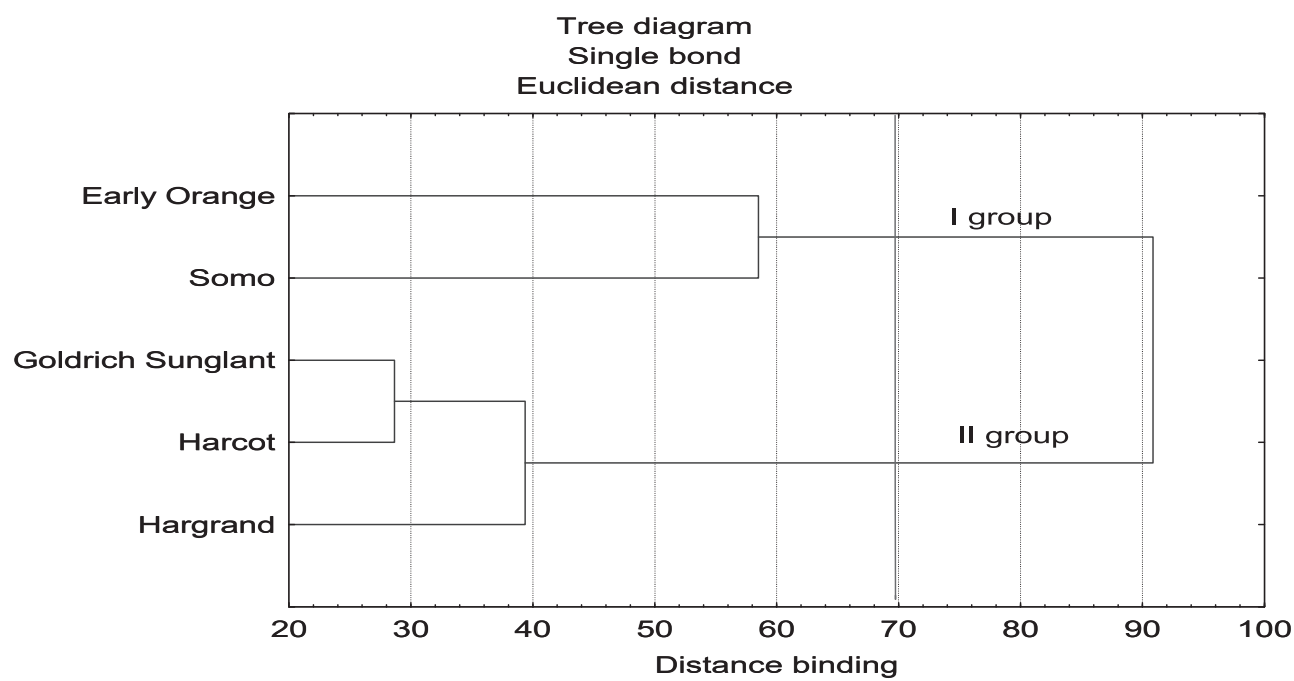

Fig. 2 Dendrogram of five apricot cultivars based on numerical data for all parameters tested in the seeds and oils.

lents of active oxygen $/ \mathrm{kg}$ oil for cold pressed and virgin oils $^{72)}$. The p-anisidine value, a common oxidation index in lipid analysis, was found to be 1.18-1.65. The oils showed absorbance values of $2.10-3.03$ and $0.87-1.07$ at 232 and $268 \lambda \mathrm{nm}$, respectively.

\subsection{Statistical comparison of the results for cultivars}

In the similarity dendrogram, two groups can be distinguished among the apricot cultivars. The 'Early Orange' and 'Somo' cultivars belong to one group, and the remaining cultivars to the other group (Fig. 2). The second group of cultivars ( 'Goldrich Sungiant', 'Harcot' and 'Hargrand' ) shows greater similarity in terms of the analysed data.

\section{Conclusion}

This study analysed the chemical characteristics and antioxidant properties of five cultivars of apricot(Prunus armeniaca L.) grown in Poland. The results have shown that apricot seeds, which are usually discarded as fruit processing waste, contain appreciable amounts of oil, which is a rich source of oleic acid (over 70\%) and $\gamma$-tocopherols (315-502 mg/kg). The oil from apricot seeds can be considered good edible oil and can also be used in the cosmetics industry as a raw material with antioxidant properties. The 'Somo' cultivar in particular can be recommended for cultivation for oil in Polish climate conditions, as this cultivar was found to have the highest oil yield and the best antioxidant properties, resulting from the highest content of bioactive compounds. This paper may be helpful in research on and practical applications of apricot oil, which can be used in various food products, pharmaceuticals and cosmetics with health benefits.

\section{Conflict of Interest}

The authors declare no conflicts of interest.

\section{References}

1) Michalak, M.; Kiełtyka-Dadasiewicz, A. Oils from fruit seeds and their dietetic and cosmetic significance. 
Herba Pol. 64, 64-71 (2018).

2) Özcan, M.M.; Özalp, C.; Ünver, A.; Arslan, D.; Dursun, N. Properties of apricot kernel and oils as fruit juice processing waste. Food Nutr. Sci. 1, 31-37 (2010).

3) Matthaus, B.; Özcan, M.M.; Juhaimi, F.A. Fatty acid composition and tocopherol content of the kernel oil from apricot varieties (Hasanbey, Hacihaliloglu, Kabaasi and Soganci) collected at different harvest times. Eur. Food Res. Technol. 242, 221-226 (2016).

4) Wani, S.M.; Masoodi, F.A.; Wani, T.A.; Ahmad, M.; Gani, A.; Ganai, S.A. Physical characteristics, mineral analysis and antioxidant properties of some apricot varieties grown in North India. Cogent Food \& Agriculture. 1 (2015). https://dx.doi.org/10.1080/23311932.2015.11 18961.

5) Gezer, I.; Haciseferoğullari, H.; Özcan, M.M.; Arslan, D.; Asma, B.M.; Ünver, A. Physico-chemical properties of apricot (Prunus armeniaca L.) kernels. South West. J. Hortic. Biol. Environ. 2, 1-13(2011).

6) Alpaslan, M.; Hayta, M. Apricot kernel: Physical and chemical properties. J. Am. Oil Chem. Soc. 83, 469471 (2006).

7) Bachheti, R.K.; Rai, I.; Joshi, A.; Rana, V. Physicochemical study of seed oil of Prunus armeniaca L. grown in Garhwal region(India) and its comparison with some conventional food oils. Int. Food Res. J. 19, 577-581 (2012).

8) Dixit, A.K.; Sharma, P.C.; Nanda, S.K.; Aleksha Kudos, S.K. Impact of processing technology in Hilly Region: A study on extraction of apricot kernel oil. Agr. Econ. Res. Rev. 23, 405-410 (2010).

9) Sharlatifar, N.; Pourfard, I.M.; Khaniki, G.J.; Nabizadeh, R.; Akbarzadeh, A.; Nejad, A.S.M. Mineral composition, physico-chemical properties and fatty acids profile of Prunus armeniaca apricot seed oil. Asian J. Chem. 29, 2011-2015(2017).

10) Manzoor, M.; Anwar, F.; Ashraf, M.; Alkharfy, K.M. Physico-chemical characteristics of seed oils extracted from different apricot (Prunus armeniaca L.) varieties from Pakistan. Grasas y Aceites 63, 193-201 (2012).

11) Raj, V.; Jain, A.; Chaudhary, J. Prunus Armeniaca (Apricot): An Overview. J. Pharm. Res. 5, 3964-3966 (2012).

12) Gilani, S.A.; Qureshi, R.A.; Khan, A.M.; Potter. D. Morphological chracterization of the pollens of the selected species of Genus Prunus Linn. from Northern Pakistan. Afr. J. Biotechnol. 9, 2872-2879 (2010).

13) Lee, H.H.; Ahn, J.H.; Kwon, A.R.; Lee, E.S.; Kwak, J.H.; Min, Y.H. Chemical composition and antimicrobial activity of the essential oil of apricot seed. Phytother. Res. 28, 1867-1872 (2014).

14) Tian, H.-L.; Zhan, P. Chemical composition and antioxidant activities of ansu apricot oil growing wild in north Xinjiang,China. Nat. Prod. Res. 25, 1208-1211 (2011).

15) Lin, T.-K.; Zhong, L.; Santiago, J.L. Anti-inflammatory and skin barrier repair effects of topical application of some plant oils. Int. J. Mol. Sci. 19, pii:E70 (2017).

16) Targais, K.; Stobdan, T.; Yadav, A.; Singh, S.B. Extraction of apricot kernel oil in cold desert Ladakh, India. Indian J. Tradit. Know. 10, 304-306 (2011).

17) Gupta, A.; Sharma, P.C.; Tilakratne, B.M.K.S.; Verma, A.K. Studies on physico-chemical characteristics and fatty acid composition of wild apricot(Prunus armeniaca Linn.) kernel oil. Indian J. Nat. Prod. Resour. 3, 366-370 (2012).

18) Yildirim, K.; Kostem, A.M. A technical glance on some cosmetic oils. Eur. Sci. J./SPECIAL/ edition 425-435 (2014).

19) Durmaz, G.; Alpaslan. M. Antioxidant properties of roasted apricot (Prunus armeniaca L.) kernel. Food Chem. 100, 1177-1181 (2007).

20) Turan, S.; Topcu, A.; Karabulut, I.; Vural, H.; Hayaloglu, A.A. Fatty acid, triacylglycerol, phytosterol, and tocopherol variation in kernel oil of Malatya apricots from Turkey. J. Agric. Food Chem. 55, 10787-10794 (2007).

21) FAOSTAT "Crops" Countries - Select All; Regions World + (Total); Elements - Production Quantity; Items - Apricots; Years - 2017+2016 (http://www.fao. org/faostat/en/\#data/QC/).

22) Licznar-Małańczuk, M.; Sosna, I. Growth and yielding of the several apricot cultivars on the 'Somo' seedling and vegetative rootstock Pumiselect ${ }^{\circledR}$. Acta Sci. Pol., Hortorum Cultus 12, 85-95 (2013).

23) Bialek A.; Bialek M.; Jedlinska M.; Tokarz A. Fatty acid composition and oxidative characteristics of novel edible oils in Poland. CyTA J. Food 15, 1-8(2017).

24) ISO 5983-1:2005 Animal feeding stuffs - Determination of nitrogen content and calculation of crude protein content - Part 1: Kjeldahl method.

25) ISO 5984:2002 Animal feeding stuffs - Determination of crude ash.

26) Indian Standard Specification No I.S 1797 - 1985 Methods of Test for Spices and Condiments.

27) ISO 6496:1999 Animal feeding stuffs - Determination of moisture and other volatile matter content.

28) ISO 3657:2013 Animal and vegetable fats and oils Determination of saponification value.

29) I. S. I. Handbook of Food Analysis. Part XIII. 67. A.O.A.C 17th ed. 2000, Official method 933.08, Residue (unsaponifiable) of oils and fats (1984).

30) ISO 6320:2000 Animal and vegetable fats and oils Determination of refractive index.

31) I.S.I. Handbook of Food Analysis XIII. 76. A.O.A.C 17th ed. 2000, Official method 920. 159 - Iodine absorption number of oils and fats (1984). 
32) ISO 5509:2000 Animal and vegetable fats and oils Preparation of methyl esters of fatty acids.

33) ISO 5508:1990Animal and vegetable fats and oils Analysis by gas chromatography of methyl esters of fatty acids.

34) PN-EN 12822:2014-08 Foodstuffs - Determination of vitamin $\mathrm{E}$ by high performance liquid chromatography - Measurement of <alpha>-, <beta>-, <gamma>- and $<$ delta $>$-tocopherols.

35) BS $684-2.20: 1977$. Methods of analysis of fats and fatty acids. Determination of carotene in vegetable oils.

36) Singleton, V.L.; Rossi, J.A.Jr. Colorimetry of total phenolics with phosphomolybdic-phosphotungstic acid reagents. Am. J. Enol. Vitic. 16, 44-158(1965).

37) Szydłowska-Czerniak, A.; Karlovits, G.; Dianoczki, C.; Recseg, K.; Szłyk, E. Comparison of two analytical methods for assessing antioxidant capacity of rapeseed and olive oils. J. Am. Oil Chem. Soc. 85, 141-149 (2008).

38) Benzie, I.F.F.; Strain, L. Ferric reducing ability of plasma(FRAP) as a measure of antioxidant power: The FRAP assay. Anal. Biochem. 239, 70-76 (1996).

39) ISO 3960:2007 Animal and vegetable fats and oils Determination of peroxide value.

40) Firestone, D. Official Methods and Recommended Practices of the American Oil Chemists' Society. AOCS Press, Champaign, IL (1994).

41) IUPAC (International Union of Pure and Applied Chemistry). Standard methods for the analysis of oils, fat and derivatives; 7 th revised and enlarged ed. $(\mathrm{Pa}-$ quat, C.; Hautfenne, A. eds.), Blackwell Scientific, London (1987).

42) Beyer, R.; Melton, L.D. Composition of New Zealand apricot kernels. N.Z. Crop Hortic. Sci. 18, 39-42 (1990).

43) Özcan, M. Composition of some apricot(Prunus armeniaca) kernels grown in Turkey. Acta Aliment. 29, 289-293 (2000).

44) Amos-Tautua, B.; Onigbinde, A. Physicochemical properties and fatty acid profiles of crude oil extracts from three vegetable seeds. Pak. J. Nutr. 12, 647-650 (2013).

45) Grajzer, M.; Prescha, A.; Korzonek, K.; Wojakowska, A.; Dziadas, M.; Kulma, A.; Grajeta H. Characteristics of rose hip (Rosa canina L.) cold-pressed oil and its oxidative stability studied by the differential scanning calorimetry method. Food Chem. 188, 459-466 (2015).

46) Tańska, M.; Roszkowska, B.; Skrajda, M.; Dąbrowski, G. Commercial cold pressed flaxseed oils quality and oxidative stability at the beginning and the end of their shelf life. J. Oleo Sci. 65, 111-121 (2016).

47) Dubois, V.; Breton, S.; Linder, M.; Fanni, J.; Parmentier, M. Fatty acid profiles of 80 vegetable oils with re- gard to their nutritional potential. Eur. J. Lipid Sci. Technol. 109, 710-732(2007).

48) Yang, B.; Kallio, H. Composition and physiological effects of sea buckthorn ("Hippophae") lipids. Trends Food Sci. Technol. 13, 160-167(2002).

49) Dubois, V.; Breton, S.; Linder, M.; Fanni, J.; Parmentier, M. Fatty acid profiles of 80 vegetable oils with regard to their nutritional potential. Eur. J. Lipid Sci. Technol. 109, 710-732(2007).

50） Łoźna, K.; Kita, A.; Styczyńska, M.; Biernat, J. Skład kwasów tłuszczowych olejów zalecanych w profilaktyce chorób cywilizacyjnych (Fatty acid composition of oils recommended in the prevention of lifestyle diseases). Probl. Hig. Epid. 93, 871-875(2012).

51) Obiedzińska, A.; Waszkiewicz-Robak, B. Oleje tłoczone na zimno jako żywność funkcjonalna (Cold pressed oils as functional food). Żywn. Nauka Technol. Jakość. 1, 27-44 (2012).

52) Kamel, B.S.; Kakuda, Y. Characterization of the seed oil and meal from apricot, cherry, nectarine, peach and plum. J. Am. Oil Chem. Soc. 69, 492-494(1992).

53) Correa, M.C.; Mao, G.; Saad, P. Molecular interactions of plant oil components with stratum corneum lipids correlate with clinical measures of skin barrier function. Exp. Dermatol. 23, 39-44(2014).

54) Michalak, M.; Glinka, R. Plant oils in cosmetology and dermatology. Pol. J. Cosmetol. 21, 2-9 (2018).

55) Feingold, K.R.; Elias, P.M. Role of lipids in the formation and maintenance of the cutaneous permeability barier. Biochim. Biophys. Acta 1841, 280-294(2014).

56) Gause, S.; Chauhan, A. UV-blocking potential of oils and juices. Int. J. Cosmet. Sci. 38, 354-63 (2016).

57) Popa, V.M.; Bele, C.; Poiana, M.A.; Dumbrava, D.; Raba, D.N.; Jianu, C. Evaluation of bioactive compounds and of antioxidant properties in some oils obtained from food industry by-products. Rom. Biotech. Lett. 16, 6234-6241 (2011).

58) Sordillo, L.M.; Aitken, S.L. Impact of oxidative stress on the health and immune function of dairy cattle. Vet. Immunol. Immunop. 128, 104-109 (2009).

59) Beckman, K.B.; Ames, B.N. The free radical theory of aging matures. Physiol. Rev. 78, 547-581 (1998).

60) Fang, Y.Z.; Yang, S.; Wu, G. Free radical, antioxidants and nutrition. Nutrition 18, 872-878(2002).

61) Han, X.; Shen, T.; Lou, H. Dietary polyphenols and their biological significance. Int. J. Mol. Sci. 8, 950988(2007).

62) Tsao, R. Chemistry and biochemistry of dietary polyphenols. Nutrients 2, 1231-1246 (2010).

63) Nichols, J.A.; Katiyar, S.K. Skin photoprotection by natural polyphenols: anti-inflammatory, antioxidant and DNA repair mechanisms. Arch. Dermatol. Res. 302, 71-83 (2010).

64) Wojdyło, A.; Oszmiański, J.; Czemerys, R. Antioxidant 
activity and phenolic compounds in 32 selected herbs. Food Chem. 105, 940-949 (2007).

65) Jain, P.K.; Kharya, M.D.; Gajbhiye, A.; Sara, U.V.S.; Sharma, V.K. Flavonoids as nutraceuticals. A review. Herba Pol. 56, 105-117 (2010).

66) Anunciato, T.P.; da Rocha Filho, P.A. Carotenoids and polyphenols in nutricosmetics, nutraceuticals, and cosmeceuticals. J. Cosmet. Dermatol. 11, 51-54 (2012).

67) Shi, L.; Zheng, L.; Zhao, Ch.; Jin, Q.; Wang, X. Chemical composition and antioxidant capacity of extracts from the whole berry, pulp and seed of Hippophae " rhamnoides ssp. yunnanensis. Nat. Prod. Res. (2018). DOI: 10.1080/14786419.2018.1488703.

68) Demir, N.; Yildiz, O.; Alpaslan, M.; Hayaloglu, A.A. Evaluation of volatiles, phenolic compounds and anti- oxidant activities of rose hip (Rosa L.) fruits in Turkey. LWT-Food Sci. Technol. 57, 126-133(2014).

69) Szentmihályi, K.; Vinkler, P.; Lakatos, B.; Illés, V.; Then, M. Rose hip (Rosa canina L.) oil obtained from waste hip seeds by different extraction methods. Bioresour. Technol. 82, 195-201 (2002).

70) Nayak, B.S.; Ramdath, D.D.; Marshall, J.R.; Isitor, G.; Xue, S.; Shi, J. Wound healing Properties of the Oils of Vitis vinifera and Vaccinium macrocarpon. Phytother. Res. 25, 1201-1208(2011).

71) Oomah, B.D.; Ladet, S.; Godfrey, D.V.; Liang, J.; Girard, B. Characteristics of raspberry (Rubus idaeus L.) seed oil. Food Chem. 69, 187-193 (2000).

72) Codex Alimentarius FAO/WHO Food Standards: Codex Standard for named vegetable oils, Codex Stan 210 (CX-STAN 210 - 1999). 